\title{
Imperative Speech in Learning Process at TK Badak Mekar, Muara Badak, Kutai Kartanegara: A Pragmatic Analysis
}

\author{
Yusak Hudiyono ${ }^{1}$, Suhana ${ }^{2}$ \\ FKIP Mulawarman University ${ }^{1}$ FKIP Mulawarman University ${ }^{2}$ \\ Email: yusak.hudiyono@fkip.unmul.ac.id ${ }^{1}$, Email: suhana@yahoo.co.id ${ }^{2}$
}

\section{Keywords : \\ imperative speech; learning process; pragmatic analysis}

\begin{abstract}
This study aims to describe the speech of kindergarten teachers Badak Mekar, Muara Badak, Kutai Kartanegara covering (1) imperative form, (2) imperative politeness. Data analysis used conversational analysis with pragmatic analysis technique. The validity of the data is obtained through observational persistence and triangulation is done during the teaching process. Data collection is done by tapping technique (participant observation), recording techniques, and collect as many as 124 imperative speeches. The results of the first study (1), the imperative form in the speech of the kindergarten of the Badak Mekar kindergarten include (a) the most commonly found structural form is the non-transitive active and passive imperative and $(b)$ the most commonly found pragmatic form is the imperative form (command construction). (2) Secondly, the imperative courtesy of the teacher's speech includes (a) the most commonly found linguistic politeness is a gentle word, a low tone of speech, and polite kinesics gestures, and (b) the most common pragmatic pronunciation is maxima consensus and there is also a combination of two to three maxims. Pragmatic pronunciation based on the most commonly found speech constructions is declarative and interrogative construction.
\end{abstract}

\section{INTRODUCTION}

Imperative is a speech spoken by a speaker to provide an order, direction, advice or command. Imperative tutelage has a very significant communicative function and is always used in daily communication. In communicative imperative speech can also be delivered in writing or verbally. Written imperative speeches usually end with an exclamation mark (!), In contrast to oral pragmatic examinations. Pragmatically, the news (declarative) and question (introgative) statements other than functioning to preach or ask, also serves to command or rule (imperative). In this case, the pronunciation of declarative or introgative constructively can be imperative.

Based on the exposure, this focus is the imperative speech of Kindak Mekar Kindergarten teachers, Natural Gas Village, Muara Badak Subdistrict, Kutai Kartanegara District. Interest in Badak Mekar Kindergarten is an easy-to-reach setting that simplifies the process, Kindergarten Kindergarten is also the kindergarten or kindergarten in Muara Badak sub-district. Therefore, the writer is interested in analyzing in terms of imperative form and imperative politeness in Kindak Mekar Kindergarten teachers in Desa Alam Alam, Muara Badak Subdistrict, Kutai Kartanegara District. 
Pragmatic study is a linguistic study that takes into account the context in his speech in speech events between speakers and opponents. While Leech (2011: 8) defines pragmatic as one of the linguistic fields that examines the meaning in relation to the situation of speech situations that include the contributing elements and the addressed, context, purpose, ilocution, speech, time, and place. Basically the meaning in pragmatic is the external meaning, the meaning that always takes into account the meaning of the speakers associated with the speaking situations. Related to the context, Levinson (in Rahardi, 2008: 48) defines pragmatic as a language study studying language relations with his contest. The intended context is americized and modified so it can not be relinquished from the language structure

Speech Occurrence is the occurrence or ongoing linguistic interaction in one or more forms of speech involving two parties, speakers and opponents, with a single essay within a specific time, place and situation. The process of teaching and learning is a teacher's activity delivering goals to their learners. This is, in accordance with the task of the teacher to convey information, so that the learners can increase their knowledge, increase their knowledge, and attitude and behavior and have a positive outlook for a better life.

According Rahardi (2008: 71) in Indonesian there are forms and communicative values of the sentence. The imperative sentence is a sentence of command or imperative is a sentence which means giving a command to do something. Sentences that can have the form of command in general are nontransitive or passive sentences. Rahardi (2008: 79) also defines an imperative sentence containing the purpose of commanding or requiring a partner to do something as the speaker wants. The imperative sentence in Indonesian can range from a very loud or abusive instruction to a very subtle and decent application. Imperative sentences can also range between instructions for doing something up to the prohibition to do something.

According to Rahardi (2008: 87) which is defined as an imperative structural form (Rahardi, mentioning the term formal imperative) is the realization of imperative intent when it is attributed to structural characteristics. The structural features in imperative speech include two imperative forms of active imperative and passive imperative as described below. (1) Transitive Active Imperative is a transitive active sentence that is an active verbal sentence whose P-length is followed by the funtor $\mathrm{O}$ (object), whether the funtor O (object) is expressed explicitly or implied (Suhardi, 2008: 157). Imperative in Indonesian can be active transitive. Rahardi (2008: 90) explains to form a transitive active imperative speech is to eliminate the subject that is usually a second persona, the verb should be made without starting me $(\mathrm{N})$-, and usually adding particles-to refine the imperative intent. The following example can be used to clarify this. (2) Non-Transitive Active Imperatives. The nontransitive active sentences are verbal sentences whose P-lengths are not followed by other elements that fill the fungtor $\mathrm{O}$ (objects), either directly or indirectly, nor are they followed by Pel (complement) fungtor (Suhardi, 2008: 158). According to Rahardi (2008: 88) imperative in Indonesian can be non-transitive. The act of non-transitive actual imperative can be formed from declarative speech with the requirement of eliminating the subject usually in the form of a second person maintaining the verb form used in the sentence and usually adding particles-to refine the imperative intent.

Based on the background, the formulation of this problem is as follows: (1) How is the imperative of teacher's speech in teaching and learning process in Badak Mekar Kindergarten, Desa Alam Alam, Muara Badak Subdistrict, Kutai Kartanegara Regency? (2) How is the mentality of teachers' perceptions in teaching and learning process in Badak Mekar Kindergarten, Gas Alam Village, Muara Badak Subdistrict, Kutai Kartanegara Regency?

\section{METHOD}

This type is a qualitative descriptive type. According to Djajasudarma (1993: 10) qualitative is a certain tradition in social science fundamentally dependent on human observations in its own area and relating to the community through its language. Furthermore Djajasudarma (1993: 12) says that the 
method is the tools, procedures, and techniques selected in executing (in collecting data). The language method is closely related to the purpose of the language.

The descriptive type is to collect as much data about imperative speech in Kindak Mekar Kindergarten teachers. Descriptive types are those that only provide an overview or description of results objectively or in a way. this illustrates what is about the imperative speech of Kindak Mekar Kindergarten teacher when the teaching process takes place taking into account the context of its speech.

Nawawi (1990: 63) is a descriptive type of problem-solving procedure investigated by describing or describing a person's subject or object. In this, to illustrate the imperative speech of Kindak Mekar Kindergarten teacher in Desa Alam Alam, Muara Badak Subdistrict, Kutai Kartanegara District. This descriptive can provide the characteristics, attributes and illustrations of data through the collection of data that has been collected. The data contained in these are words, if any of these numbers are used only to support in describing the results. Thus, this will always consider the data in terms of the character of the data itself. this does not seem to be something that is so in existence but must be examined based on scientific considerations used as a tool of study.

Data analysis is an attempt to classify or group data. This data analysis technique uses Pragmatics Practice, which is to examine or find the identity of a specific lingual unit by using a definite tool that is out of the language (Surdaryanto, 1993: 13). The instructional tool referred to in this is the context of the speech that includes the background of the place, the atmosphere, and the opponent in the form of reaction. In this is a student reaction to the kindergarten teacher's speech

\section{RESULTS AND DISCUSSIONS}

\section{A. Imperative}

In the kindergarten in kindergarten there is an imperative form that is formal / structural and pragmatic. Based on the following data analysis results.

a. There are transitive active imperative speeches, there are 32 data,

b. there is no transitive active imperative speech, there are 48 data,

c. There are passive imperative passages, there are 46 data,

There is an imperative pragmatic speech that is, (1) command, verbal direct command there are 40 data, (2) instruction, direct instruction directly there are 6 data that is data while indirect verbal there are 2 data, that is introgative and song data. (3) Demand, direct demand is 7 data. While the utterance of the request is indirectly there is no speech data. (4) persuasion, verbal persuasion directly there are 7 data While verbal persuasion there are 10 data, namely declarative and introgative data. (5) The appeal, the direct appeal is not there any speech data. While the verbal invitation is indirectly there is 1 data, namely declarative data. (6) call, the call to action directly there are 12 data While the indirect dialogue call there is 1 data, that is the data song. (7) granting permission, direct speech giving 4 data that is data, while the verbal giving is indirectly there is no speech data. (8) prohibition, there is a direct ban on 6 data that is data. While the prohibition of the ban is indirectly there is no speech data. (9) curse, verbal curse directly no speech data. While indirect verbal speech there are 2 data, namely declarative and introgative data. (10) congratulatory messages, direct speech greetings directly there are 2 datas of the speech of the greeting of indirectly no speech data. (11) The suggestion, the direct suggestion is directly 10 data, While the indirect speech is 1 data, namely the declarative. (12) In the past, there is directly 1 data, namely data (36). While the talk is indirectly there is no speech data. (13) Threats, direct threats say 5 data. While the threat of speech is indirectly there is no speech data. (14) Incomplete, speaking of innuendo directly there is no speech data. While indirect speech is 4 data, ie declarative and introgative.

Based on the result of imperative form, it can be concluded that from the formal / structural form of imperative speech often used in the imperative speech of TK teacher Mekar Alam Natural Village 
Muara Badak Subdistrict Kutai Kartanegara District in the process of learning activity is the form of non-transitive active imperative speech that is 48 data, then there is a passive imperative narrative that is with 46 data, then there is transitive active imperative narrative with 32 data and from pragmatic form of imperative speech that is often used in imperative speech TK teacher Badak Mekar Natural Gas Village Kecamatan Muara Badak Kutai Regency.

Kartanegara in the process of learning activities is directly the verbal command with 40 data, then indirectly ie declarative speech with 9 data, then introgatif 9 data and song 8 data. Of the seventeen existential fourteen imperative pragmatic expressions contained in this, but twelve are imperative pragmatic expressions we know whereas the two meanings of the threat and satire are the findings of this.

\section{B. Imperative Remuneration}

This imperative politeness is in parenting in kindergarten. Imperative politeness, linguistic politeness and pragmatic politeness. Based on the following data analysis results.

a. The most commonly found imperative linguistic affection is the low or medium speech intonation ie 126 data, having a polite cinesic signature that is 126 data, a non-abusive word choice of 125 data, long speech that is 78 data, there is a marker of politeness that is 38 data, the sequence of speech: there non imperative information is 14 data, and partial verb assert 1 data.

b. The most commonly found imperative pragmatic affection is the maxim of sobriety, which is 81 data, the maxim of wisdom + concert, that is 20 data, the maxim of wisdom is 9 data, the maxim of wisdom + praise + concordance that is 6 data, maximity of generosity + that is 5 data, maxim wisdom + sympathy namely 2 data, maxim sympathy + concert that is 2 data, maxim wisdom + compliment that is 1 data, and compliment + concert that is 1 data.

Based on imperative politeness results it can be concluded that imperative linguistic politeness has different imperative linguistic characteristics in the use of teacher imperative speech depending on the situation and condition of the classroom. While the imperative pragmatic affection, of the six imperatives pragmatic affairs are only five of the maxims contained in this, namely, 1) maxim of wisdom, 2) maxim of communion, 3) maxim of praise, 4) maxim of sympathy and 5) maxim of philanthropy.

\section{A. The Imperative of a Kindergarten Teacher}

Based on the result of this research, there is imperative form that is formal / structural imperative and imperative pragmatic form. formal / structural existence is active and passive. Active form is divided into two: active transitive and non-transitive active. There are fourteen pragmatic forms and two pragmatic forms of data analysis, the pragmatic form (1) command, (2) instruction, (3) request, (4) persuasion, (5) appeal, ( 6) invites, (7) granting permits, 8) prohibitions, 9) harassment, 10) giving congratulations, (11) advice, (12) confrontation, 13) threats, and 14) satire. Seeing this kind of thing the teacher has actually used all forms of imperative in learning. It is highly recommended for use of a variety of imperative forms of use as it will be an input for learners to practice and obtain pragmatic acquisitions. According to the hypothesis of the acquisition there is an input / input to the acquisition of both languages of both students in the form of discourse inputs and texts (Ellis, 1995: 246).

Based on an analysis of imperative pragmatic speech can be seen from 126 imperative narrative data which imperatively means more narrative that contains the most pragmatic imperative meaning of command that is direct 40 verbal data and indirectly 5 data. This means that teachers of Kindak Mekar Kindergarten often use imperative speech with the meaning of the command because the meaning of the command has a more firm imperative value that allows a partner to not reject the command. Here is one of the following examples: 
Speech patterns that use the principle of politeness in the learning process are also something that needs to be done. Basically teachers' treatment using diverse politeness patterns is also a lesson for learners. How the students speak is greatly influenced by the teacher's speech. Thus, when a teacher's speech leads to a speech that contains politeness then the student will follow and become the acquisition for him.

In a teacher's study using a pragmatic gesture pattern imperative pragmatic politeness based on the principles of politeness found does not always only meet one maxim but may be a combination of two to three maxims. The ninth category is 1) the maxim of wisdom, 2) the maxim of wisdom and concordance, 3) the maxim of wisdom and praise, 4) the maxim of wisdom and sympathy, 5) the maxim of wisdom, praise, and concordance, 6) maxim of communion, 7) maxim of philanthropy and convention, 8) maxim of praise and grace, and 9) maxim of sympathy and conciliation. The imperative verbs with the most common engagement are found, in the form of action as a student's reaction to the teacher's imperative speech.

Based on the results and discussion on the imperative speech of Kindergarten teachers of Badak Mekar Desa Alam Alam Muara Badak subdistrict Kutai Kartanegara district. Pragmatic study, can be summarized as follows.

1. The form of imperative speeches of Kindak Mekar Kindergarten teachers is classified into two forms as follows: (a) The most commonly found formal / structural imperative is the non-transitive active and imperative imperative imperative. (b) The most commonly found pragmatic imperative is an imperative form, which is a speech in imperative construction.

2. The imperative politeness of the kindergarten teacher of the Badak Mekar is categorized into two theories as follows: (a) Linguistic affirmation (b) Pragmatic decency.Pragmatic decency includes imperative pragmatic politeness based on the principles of politeness found in 9 categories. 7 categories are a combination of some maxims because a data does not always only meet one max but can be a combination of two to three maxims. The ninth category is 1) the maxim of wisdom, 2) the maxim of wisdom and concordance, 3) the maxim of wisdom and praise, 4) the maxim of wisdom and sympathy, 5) the maxim of wisdom, praise, and concordance, 6) maxim of communion, 7) maxim of philanthropy and convention, 8) maxim of praise and grace, and 9) maxim of sympathy and conciliation. The imperative verbs with the most common engagement are found, in the form of action as a student's reaction to the teacher's imperative speech.

\section{CONCLUSION AND SUGGESTION}

Based on the above conclusions, the suggestions the writer writes, as it is. (1) The authors expect the attention of linguists to pay attention to the imperative imperative and imperative implications used by Kindak Mekar Kindergarten teachers, Natural Gas Village, Muara Badak Subdistrict, Kutai Kartanegara District. (2) Needs a broader and complete advance on imperative form and imperative genius used by Kindak Mekar Kindergarten teachers, Natural Gas Village, Muara Badak Subdistrict, Kutai Kartanegara District. (3) Needs more references to campus, city, or proprietary references related to imperative speech and imperative politeness. (4) Scientific executives such as this should have the full support of various related parties, such as Kutai Kartanegara Regency government as a concern for the language that often occurs in every language activity so that this language needs to be known

\section{REFERENCES}

Akhadiah, Sabarti et al. (1997). Language Writing Capability Development. Jakarta: Erlangga. Alwi, Hasan. (2003). Grammar of Bahasa Indonesia. Jakarta: Balai Pustaka.

Alwi, Hasan . 2011). Bahasa Indonesia: Pemakai dan Pemakainya. Jakarta: Rineka Cipta.

Chaer and Agustina, (2004). Sociology of Introduction. Jakarta: PT Rineka Cipta.

Ellis, Rod. (1995). The Study of Second Language Acquisition. Oxford: Oxford University Press.

Kartomihardjo, Soeseno. (1988). Language of Mirror of Community Life. Jakarta: Depdikbud. 
Leech, Geoffrey. (2011). Pragmatic Principles (named M. D. D. Oka). Jakarta: University of Indonesia Press.

Mahsun, (2005). Language Methods, Strategic Stages, Methods, and Techniques. Jakarta: PT Radja Grafindo Persada.

Miles. M. B. and Huberman. A. M. (1984). Qualitative Data Analysis. Translation Tjetjep Rohendi. 1992. Jakarta: University of Indonesia (UI) Press.

Moeliono, Anton. (1992). Grammar of Bahasa Indonesia. Jakarta: Balai Pustaka.

Nababan. PNJ. (1987). Pragmatic Knowledge (Theory and Its Application). Jakarta: PPLPTK.

Nadar, F.X. (2009). Pragmatic \& Pragmatic. Yogyakarta: Graha Ilmu.

Rahardi, Kunjana. (2008). Pragmatic, Imperative Approach of Bahasa Indonesia. Jakarta: Erlangga.

Soeparno. (2002). General Linguistic Basics. Yogyakarta: PT Tiara Wacana Yogya.

Sudaryanto. (1993). Methods and Various Language Analysis Techniques, Introduction to Linguistic Culture Vehicles. Yogyakarta: Duta Wacana University Press.

Sudaryat, Yayat. (2009). Meaning in Discourse of Semantic and Pragmatic Principles. Bandung: Yrama 